\title{
Editorial
}

\section{Si-Related Solar Cells for a Low Cost and High Efficiency 2013}

\author{
Junsin Yi, ${ }^{1}$ Bhushan Sopori, ${ }^{2}$ C. W. Lan, ${ }^{3}$ Donghwan Kim, ${ }^{4}$ and Stephen Bremner ${ }^{5}$ \\ ${ }^{1}$ Department of Electronic and Electrical Engineering, Sungkyunkwan University, 300 Chunchun-dong, \\ Suwon 440-746, Republic of Korea \\ ${ }^{2}$ National Renewable Energy Laboratory, Golden, CO, USA \\ ${ }^{3}$ Department of Chemical Engineering, National Taiwan University, Taipei 106, Taiwan \\ ${ }^{4}$ Department of Materials Science and Engineering, Korea University, Anam-dong 5-1, Seongbuk-gu, Seoul 136-713, Republic of Korea \\ ${ }^{5}$ School of Photovoltaic and Renewable Energy Engineering, University of New South Wales, Sydney 2052, Australia
}

Correspondence should be addressed to Junsin Yi; yi@yurim.skku.ac.kr

Received 20 November 2013; Accepted 20 November 2013

Copyright (C) 2013 Junsin Yi et al. This is an open access article distributed under the Creative Commons Attribution License, which permits unrestricted use, distribution, and reproduction in any medium, provided the original work is properly cited.

As the global effort dedicated to "green growth and lowcarbon society" has opened a new era for the renewable energy technology like solar cell, expected solar cell production capacity is expected to exceed $50 \mathrm{GW}$ in 2013 . Recent technical breakthrough in traditional wafer silicon, thin-film solar cells, and new concept of solar cells contributed to lower prices and higher efficiencies for PV energy. There has been great amount of investment in solar cells and subsequent technical breakthough. One of the key technologies is based on incident light trapping for better output power gain in various solar cells such as c-Si, mc-Si, a-Si, III-V, II-VI, CdTe, and CIGS. The sharing of new ideas and information in an open forum will allow even greater progress to be made in solar cell research and development. Potential topics include, but are not limited to: silicon surface texture methods and technologies, TCO light trapping related approaches for thin film soalr cells, plasmon related light path length modulation, substrate (glass, metal, and plastic) surface light trapping structure, high efficiency approaches and technologies with solar cell light trapping, novel solar cells related new process, material, and structure of light trapping, low cost related material, device, and process, and other novel solar cell materials and devices.

The papers collected together in this special issue have been sourced in two ways: firstly; roughly one-third of the papers were presented during the Global Photovoltaic Conference 2012 (GPVC 2012) that was held at Busan, Korea, in November 2012. Around 400 papers were presented at this conference, with outstanding presentations invited to be submitted as full-length version papers for this special issue. Secondly, an open call was made to the photovoltaics community to submit new and interesting results related to, but not restricted to, silicon based photovoltaics. The high standard expected is reflected in that only approximately a little less than half of submitted papers were accepted for publication in this issue.

The range of topics considered in the papers is considerable, spanning intensive studies of conventional crystal growth technologies, novel production methods for conventional silicon solar cells, nanoinspired architectures, and even a new characterization approach. We, the editorial team, expect, due to the high quality of the papers included in this issue, that not only will good representation of the state of research in silicon based photovoltaics be achieved, but also further efforts will be spurred on by the discoveries reported.

Junsin Yi Bhushan Sopori

C. W. Lan

Donghwan Kim Stephen Bremner 

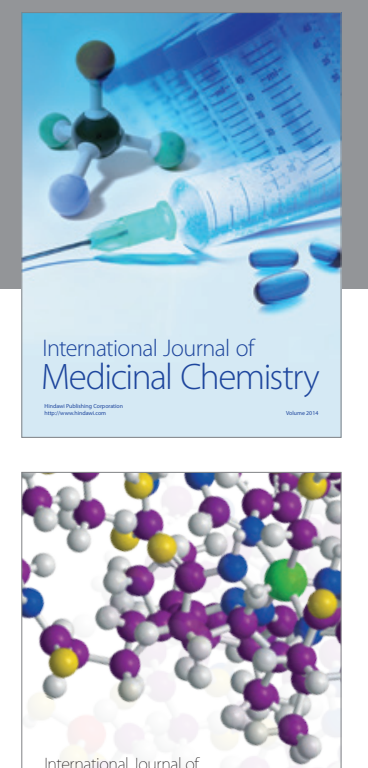

\section{Carbohydrate} Chemistry

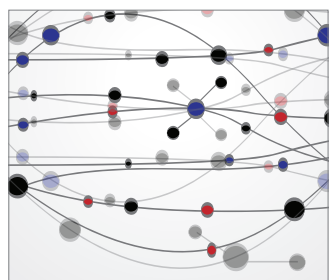

The Scientific World Journal
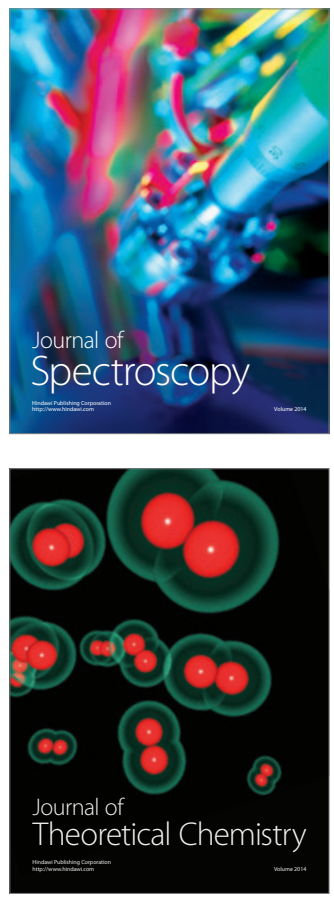
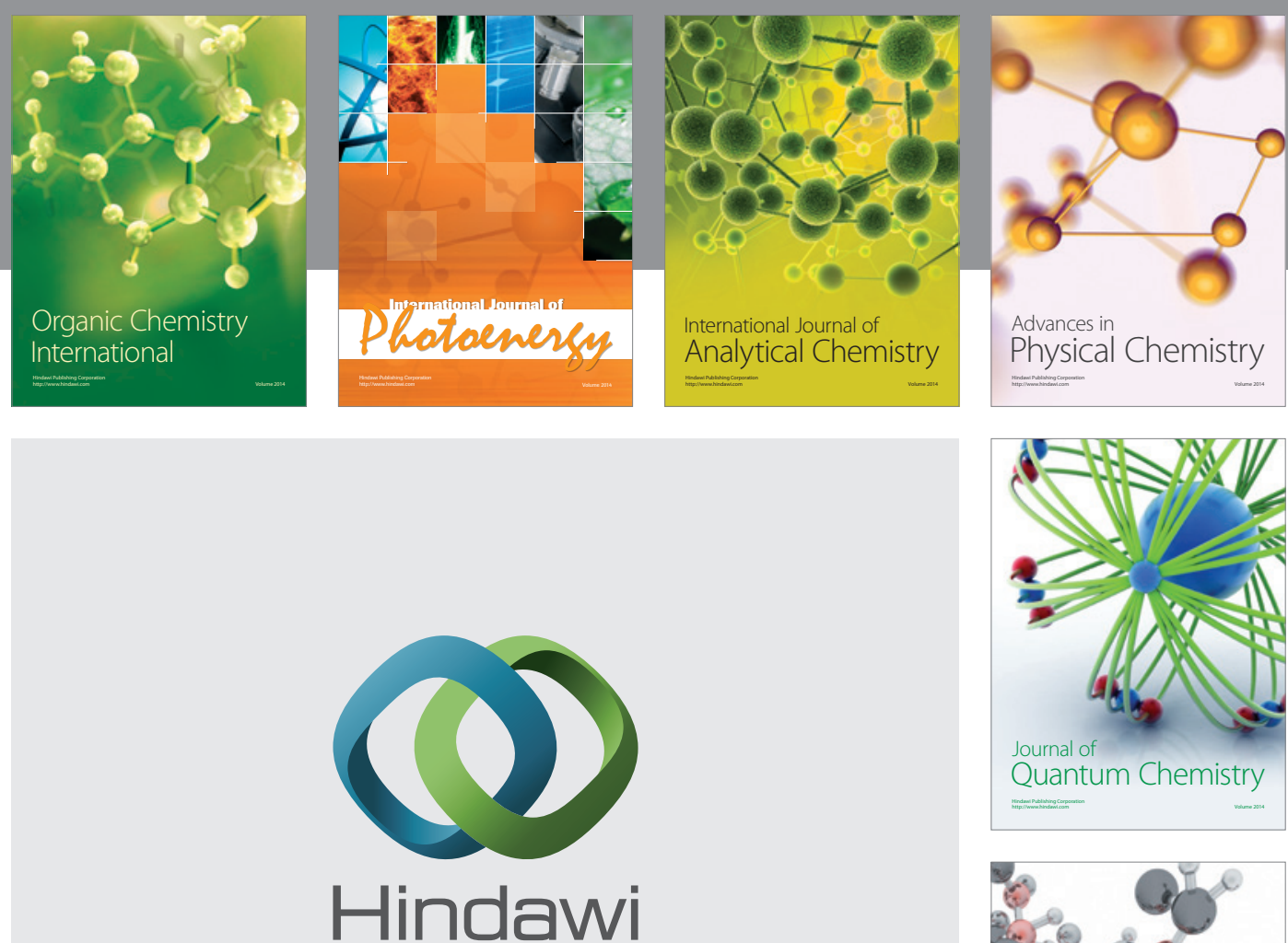

Submit your manuscripts at

http://www.hindawi.com

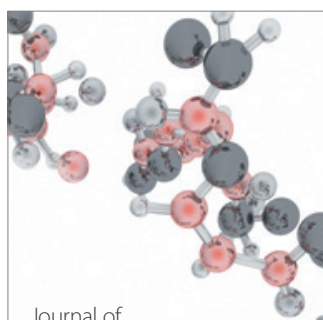

Analytical Methods

in Chemistry

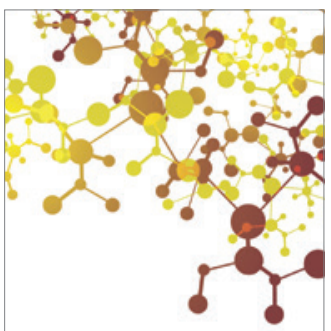

Journal of

Applied Chemistry

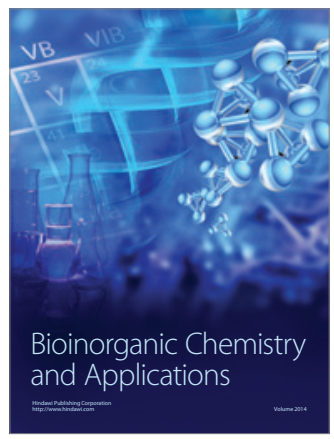

Inorganic Chemistry
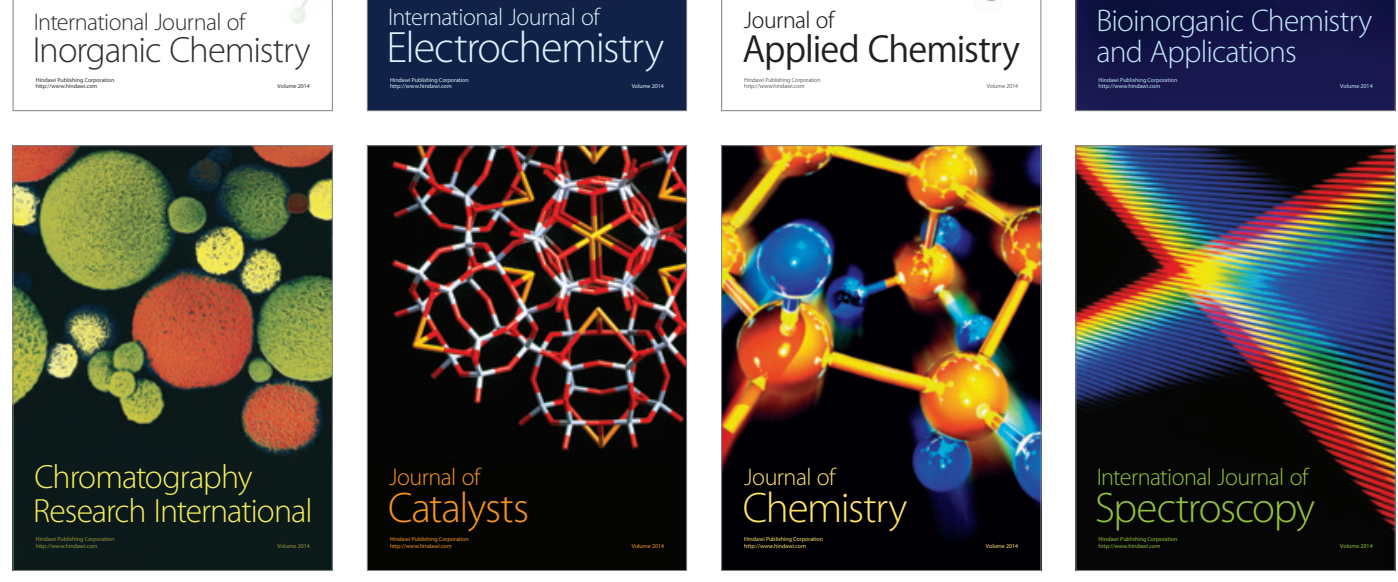